\title{
Development of Teaching Materials in the Form of E-book in Fine Arts Education and Skills of Elementary School Courses at Universitas Negeri Medan
}

\author{
$1^{\text {st }}$ Winara $^{1}, 2^{\text {nd }}$ Adek Cerah Kurnia Azis ${ }^{2}, 3^{\text {rd }}$ Muslim $^{3}, 4^{\text {th }}$ Waliyul Maulana Siregar ${ }^{4}$ \\ \{winara@unimed.ac.id ${ }^{1}$, adekcerah@unimed.ac.id ${ }^{2}$, muslim@unimed.ac.id ${ }^{3}$ \} \\ Universitas Negeri Medan, Indonesia ${ }^{1,2,3,4}$
}

\begin{abstract}
The aim of this research is; 1). Publishing books on Art and Elementary School Skills based online and in print with ISBN to publishers who are registered as members of the Indonesian Publishers Association (IKAPI); 2). Disclosure of validation, practicality, and effectiveness of teaching materials in the form of an ISBN-based online and printed book Elementary School of Flora Drawing Arts and Skills obtained from the research results $91.12 \%$ are in the very valid category, the student's modulus value is in college at a level of $90.3 \%$ can admittedly very practical, this shows that the module is able to increase user interest in the learning process, and for student activities it is included in the active category because it is in the percentage of $79.43 \%$, and 3). scientific publications in International Proceedings carried out by LPPM Medan State University, namely at the International Conference on Innovation in Education, Science and Culture and Scientific, publications in the Sinta-4 National Accreditation journal, namely the Journal of Expression of Arts, the Indonesian Institute of Science and Technology Padangpanjang.
\end{abstract}

Keywords: development, teaching materials, elementary school.

\section{Introduction}

The relationship between interest and learning outcomes, are two things that cannot be separated, a high interest in learning to a course (MK) or a course material will affect a student's learning outcomes. Interests that do not exist, of course, will affect learning outcomes that are not good too. Starting from all of that, there will be a difference if someone has more interest or desire for a course or a course material, it will certainly get better learning outcomes, of course. There are several things that can be done to foster the interest mentioned above, especially in the Elementary School of Fine Arts and Skills Education Course on Flora Drawing Materials at the PGSD Department, Faculty of Education (FIP) Universitas Negeri Medan (Unimed).

So that PGSD students have a great and high interest in learning, several things can be done to increase interest and interest in this course, among things that can be done, namely by developing Teaching Materials for Fine Arts Education Courses and Elementary Skills for Flora Drawing Materials. This development can be in the form of an e-book-based book (google book/play book and google scholar) with ISBN, and of course integrated with 
Unimed's SIPDA (Online Learning System), which aims to make it easier for students to learn and do the assignments given. by a lecturer.

Along with the development of technology to the current millennial era, there are some differences in the needs of "old" students and students of "now" era, in the past, lecturers always asked students to photocopy or buy books related to lecture material with a sufficiently thick and full copy capacity. text (containing a series of letters and numbers without any pictures), and the price of the book is quite expensive. Judging from the current state of being all gadgets, all information, be it education, health, lifestyle, and so on, is already in hand, so it is no longer suitable if a student has to photocopy thick books, then if a teaching material is full of text that is composed from the beginning to the end of the book, this is certainly very boring for students, there is no interest in reading the book, it is different if a book is interspersed with pictures or there is an arrangement of colors so that there is something different, so students become curious and interested to read the book to the end. This is reinforced by the author's interview with several students, namely [1] Sudewo and his friends on Thursday, March 11, 2021, at 22:11 PM, from the results of student answers about this it can be concluded that "all students are more interested in books that contain elements of the picture, for various reasons including easier to understand, less boring, more fun when reading it, easier to understand the theory or study discussed, and so on". Based on the interview above, here the tendency of students is clear, namely the development of teaching materials with image or visual nuances.

Furthermore, in terms of student finances, expensive book prices are no longer the time for students, with the current development, there are many flat foams that provide cheap, practical, and efficient book services, through online book applications, where students can subscribe by paying around Rp 36.000,- can have e-books forever, can be accessed anywhere and anytime via their respective smart phones, this makes it very easy for students to learn.

Based on the description of the phenomena above, there are many things that can be done to increase a student's interest in understanding the lesson and doing the tasks given by the lecturer per course, including interesting teaching media and practical, economical, and effective teaching media. efficient. Judging from the media that can increase student interest in getting better learning outcomes, especially for Fine Arts students, one of the stimuli that the author can do is to make teaching materials in the form of e-book-based books (google book/play book and google scholar). with ISBN in Elementary School Fine Arts and Skills Education Course Flora Drawing Materials in Elementary Fine Arts and Skills Education Course that can be accessed, read, viewed, and studied by PGSD students through their respective gadgets, smartphones, smartwatches, androids, and laptops -each. Students can save, share these teaching materials on the Facebook (FB), Telegram WhatsApp (WA), Email, and so on applications, which are on the gadgets owned by the student, this activity can be carried out by students wherever they are, as long as the place is connected to the internet network.

The development of teaching materials for Elementary School of Fine Arts and Skills Drawing Flora Drawing materials begins with compiling materials according to student needs, in which the presentation of the material is complemented by pictures. The preparation of teaching materials is made as attractive as possible, so that students are interested and can understand easily.

There are many ways that can be done to increase the interest and learning outcomes of PGSD students, including by developing teaching materials. [2] As said by Widodo and Jasmadi in Lestari in Putri, teaching materials are a series of facilities or something used in the teaching and learning process that contains materials, methods, limitations, and ways of 
evaluating that are designed systematically and interesting in order to achieve the desired goal, namely achieving competence or sub-competence with all its complexity. This definition illustrates that a teaching material should be designed and written with instructional rules because it will be used by lecturers, teachers, and other educators to assist and support the learning process. Learning (instructional), sources of information are lecturers, teachers, instructors, students, reading materials, teaching media, and so on. "Teaching media is a place and channel for messages from the source of the message, in this case the lecturer, to the recipient of the message, in this case the student" [3]. [4] Then Hernawan said that learning is one component that must exist, because it is a component that must be studied, observed, studied, and used as material that will be mastered by students.

Based on the description of the opinion above, it can be related in this study that teaching materials are a set of learning facilities and infrastructure and are closely related to everything that is used as a distributor of messages from the sender of the message to the recipient of the message, in this case the one who acts as the sender of the message is an educator (teacher). , lecturers, and other types of educators) to students (students, students, and other students) as recipients of the message, so that the recipients of this message become interested in the development, their interest in learning becomes high, so that it affects their high learning outcomes as well. This will be applied in the Elementary School of Fine Arts and Skills Education Course on Flora Drawing Materials in the PGSD Department later.

This Fine Arts and Skills Education course discusses theoretically and practically the concept of Fine Arts and Skills Education in Elementary Schools. Implementation and development of various techniques and educational issues to prepare students in cognitive, psychomotor, and affective aspects, so that they are ready to face science and technology and globalization. This course has the objectives of 1). Students are able to theoretically conceptualize Fine Arts and Skills Education, 2). Students are able to practically practice fine arts and work skills with various techniques, 3). Students are able to develop various working techniques, 4). Students are able to make educational media, and 5). Students are able to exhibit various works, and are able to compile reports on the results of visits.

A person's desire for something can be called an interest, where interest is closely related to a person's liking or pleasure for an object or an activity. [5] This is like what was stated by Slameto which states that interest is a sense of preference and a sense of interest in a thing or activity, without anyone telling. Interest is basically the acceptance of a relationship between oneself and something outside oneself. The stronger or closer the relationship, the greater the interest. If it is brought in learning, interest in learning has a huge influence on a learning outcome itself because, someone (student) will work seriously, well, and correctly with something that he is interested in [6].

Furthermore, [7] Azis reveals that interest is a preference for something that arises from within (internal) and influences from outside (external). This interest arises without any coercion from anyone, is a will of oneself, the thing that is of interest is something that is interesting to have or do for a future career. Based on the description of the interests above, it is hoped that the development of teaching materials in the form of comics in the Elementary School of Fine Arts and Skills Educational Flora Drawing Materials in the PGSD Department can increase the interest of PGSD Department students who arise from within (internal) interest in something that Interest comes from outside oneself (external), causing the desire to approach, study, touch, and so on more closely, so that it gains the desire to study higher and of course obtain high learning outcomes as well.

A result is carried out after carrying out learning activities then conducting an assessment and obtaining results, the results are high, moderate, and some are low, here it can be seen that 
learning outcomes will be determined from the interest in learning itself, which will be directly proportional if interest in learning is high then learning outcomes are of course high, and vice versa. Learning achievement is the mastery of knowledge or skills developed through subjects (MP), usually indicated by test scores or scores given by a lecturer [8]. [9] Furthermore, Hamalik reveals about learning outcomes, that a learning outcome is a change in behavior in a person that can be observed and measured in terms of knowledge, attitudes, and skills. These changes can be interpreted as an increase and development that is better than before where those who do not know become aware. Learning outcomes are influenced by many factors, including health, psychological, and could also be due to fatigue, but there are other important factors, namely from family, school or campus (media or teaching materials), and also from the community [10].

Based on the description above, it can be concluded that learning outcomes are the values obtained by a student (in this case a student) after participating in learning, carrying out tests, in the form of numbers or letters. So the learning outcomes here are all outputs in the form of numbers or statements of high interest in learning because of the innovation of interesting teaching materials so as to obtain high learning outcomes as well. A learning process, of course, in the future, will get the good or bad of the ability of students' learning outcomes [11].

Drawing is one of the visual arts activities that includes creativity, taste, and intention that are realized in the form of two-dimensional works. Drawing natural objects is one of the inspirations that can be done. Because the objects are all around us, the easiest things to find are flora, fauna, and the outdoors such as mountains, beaches, or rivers [12]. The definition of drawing is to make scratches on the surface that graphically show the resemblance of an object. In the process of drawing, it presents a separate reality that is equivalent to experiences. Such graphical presentation is a very important way to record observations, give shape to what is visualized and communicate various thoughts and concepts. Drawing flora is the process of transferring the shape of an object, such as the shape of leaves, flowers, and fruit. The parts can be drawn separately or combined into a unified whole and interesting.

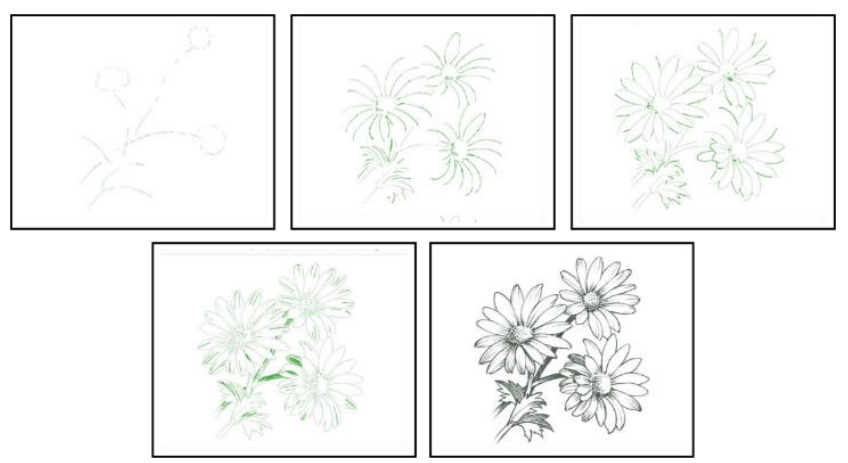

Fig. 1. Stages of Making Flora Images. 


\section{Method}

Based on the purpose of this research, which is to produce teaching materials or learning modules based on e-books (google books/play books and google scholar) with ISBNs that are valid, practical, and effective, therefore, this research is included in this type of research. development (development research). The following is a flow chart of the research and development that will be carried out:

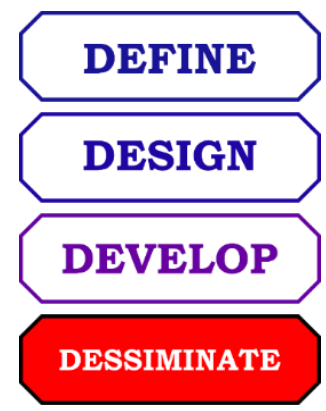

Fig. 2. Research Development Flowchart.

This research will be conducted using 4D models (four-D models). The development of the four-D model consists of 4 (four) stages: 1). Definition (define), 2). Design (design), 3). Development (develop), and 4). Spread (dessiminate) [13]. This research only reached the development stage, namely stage 3 (three), while the disseminate was not carried out, citing time and cost constraints of course. The research location is focused on the PGSD Department, Faculty of Education

Unimed, the object of this research is PGSD students who are taking the Elementary School of Art and Skills Drawing Flora Drawing Course, there are classes A, B, C, D, and E each class can be averaged 30 students. The research was conducted in the Even Semester of the 2020/2021 Academic Year on the PGSD Department Student's course schedule in the Elementary School of Fine Arts and Skills Education Course on Flora Drawing Materials in the PGSD Department.

The population in this study were all students of Fine Arts who were taking the Elementary School of Arts and Skills Elementary School of Drawing Flora in the PGSD Department, in line with the author [14] opinion "if the population is more than 100, a sample of $10 \%$ can be taken. up to $15 \%$ or $20 \%$ to $25 \%$ or depending on the ability of the researcher. Seeing this condition, the sampling in this study used a random sampling technique, where considering the large number of existing populations, to speed up time and simplify the number of populations, a $10 \%$ sample was taken. The sample was chosen randomly, namely by revocation using the lottery technique (lottery), which was taken as a sample in this study. So, the sample in this study, which was selected from the entire population of 15 people, can be seen in full in table 1 below: 
Table 1. Population and Sample.

\begin{tabular}{ccc}
\hline Class & Population & Sample \\
\hline A & 30 people & 3 people \\
\hline B & 30 people & 3 people \\
\hline C & 30 people & 3 people \\
\hline D & 30 people & 3 people \\
\hline E & 30 people & 3 people \\
\hline Amount & $\mathbf{1 5 0}$ people & $\mathbf{1 5}$ people \\
\hline
\end{tabular}

\section{Results and Discussion}

\subsection{Validation}

The results of the validation of each validator obtained a score as follows:

Table 2. Validator Assessment Results.

\begin{tabular}{ccc}
\hline Variable & Achievement (\%) & Category \\
\hline Module Contents & $90 \%$ & Very Valid \\
\hline Construction & $91 \%$ & Very Valid \\
\hline Language & $90 \%$ & Very Valid \\
\hline Module Display & $93.5 \%$ & Very Valid \\
\hline Average & $\mathbf{9 1 . 1 2 \%}$ & Very Valid \\
\hline
\end{tabular}

Analysis of the validator's assessment score of 4 (four) variables describes that, 1). The module contents is at the achievement of a score of $90 \%$ in the very valid category, 2). Construction is at $91 \%$ into the very valid category, 3). Language variable is at $90 \%$ into the very valid category, and 4). Display Modules are at $93.5 \%$ fall into the very valid category as well. Based on the achievement of the score above, it can be taken the average of the four variables $91.12 \%$ of the average results are included in the very valid category. Comparison of the degree of achievement of module validation results on each variable that has been assessed by the validator can be seen in figure 3 below:

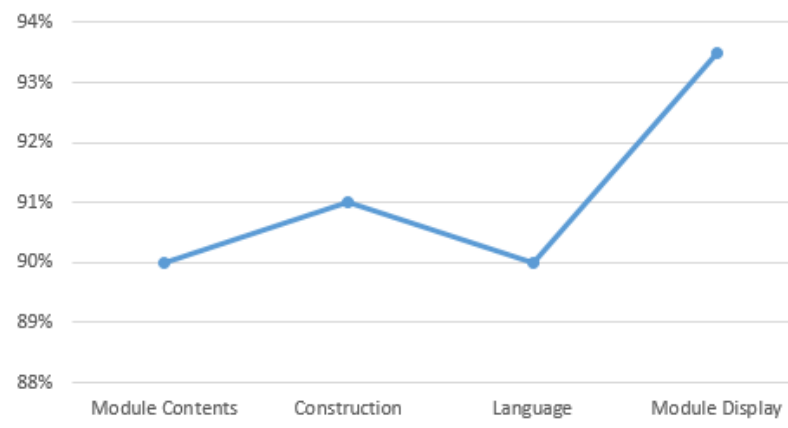

Fig. 3. Validator Assessment Results. 


\subsection{Module Practicality}

The results of the practicality of the module from this study obtained the following data:

Table 3. Student Practical Results

\begin{tabular}{ccc}
\hline Variable & Achievement (\%) & Category \\
\hline Convenience for users & $90 \%$ & Practical \\
\hline Usability & $93 \%$ & Very Practical \\
\hline Time effectiveness & $90 \%$ & Very Practical \\
\hline Average & $\mathbf{9 0 . 3 \%}$ & Very practical \\
\hline
\end{tabular}

The results obtained from the Elementary School of Arts and Skills Elementary School of Drawing Flora in the PGSD Department, Universitas Negeri Medan which is also the object of testing this module, there are 3 (three) variables, namely 1). Ease for Users (Learnability) with an achievement of $88 \%$ feels in the practical category, 2). Efficiency is at the achievement of $93 \%$ in the very practical category, and 3). The Effectiveness of Time is at $90 \%$, this shows that it is in the very practical category. Effectiveness in the teaching and learning process is a quality standard that has a measure of achieving goals, it can also be said to be precise in managing a situation or also called "doing the right things". The average value of practicality by students with an achievement level of $90.3 \%$ then from these results it can be said that the module is in the very practical category. More clearly the achievement of module practicality by students can be seen in figure 4 below:

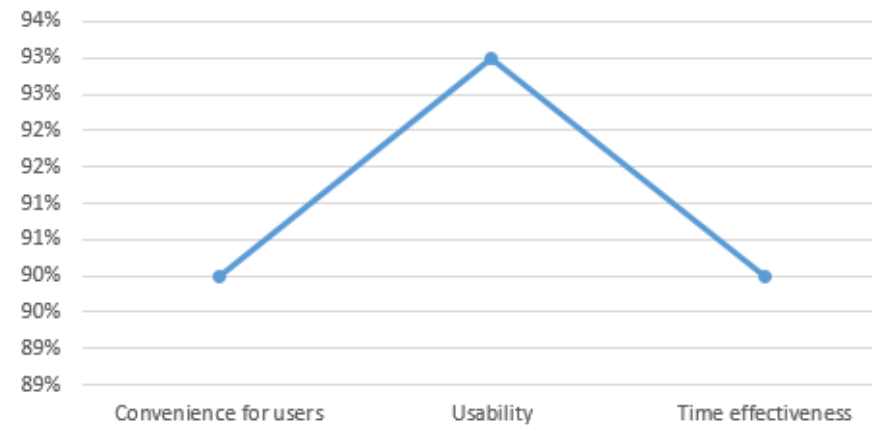

Fig. 4. Student Practical Results.

\subsection{Module Effectiveness}

Some of the activities seen by observers are as follows: a). Reading modules and doing exercises; b). Giving questions to the lecturer concerned while participating in the teaching and learning process; c). Provide answers to all the questions given by the lecturer concerned; and D). Collect assignments given by the lecturer. The first activity was reading the module and doing the exercises, the presentation of student activities reading the module and doing the exercises from the first meeting to the second meeting was at 100\%, 100\%, 100\%, and 100\%. On average $100 \%$ entered into the active category once. In the second activity, students asked questions to the lecturer while participating in the teaching and learning process. The 
percentages of activity from the first meeting to the fourth meeting are as follows: $67 \%, 59 \%$, $50 \%$, and $55 \%$, with an average of $57.75 \%$, so they fall into the fairly active category. Based on the data above, students who asked questions to the lecturers at these four meetings experienced a decrease in the second and third meetings, but increased in the fourth meeting. It can be said that learning using modules can improve student learning outcomes.

In the third activity, students answered questions from lecturers and questions from colleagues. The percentages of these four meetings are as follows: $60 \%, 59 \%, 60 \%$, and $61 \%$, so it can be averaged $60 \%$. This can be categorized as active students. Based on the percentage data above, it can be said that students experienced an increase from the first meeting to the fourth meeting in answering questions from lecturers and colleagues. The fourth activity completes the tasks given by the lecturer. All students collect their assignments from the first meeting to the second meeting where the percentage for each meeting is as follows: $100 \%$, $100 \%, 100 \%$, and $100 \%$, with an average student activity of $100 \%$, it can be categorized as a student very active. The tasks given must be completed by each individual, so each student has responsibility for the tasks given by the lecturer. The average student activity above from each category can be seen in general in table 4 below:

Table 4. Module Effectiveness Results.

\begin{tabular}{ccc}
\hline Student Activity Category & Achievement (\%) & Category \\
\hline $\begin{array}{c}\text { Reading modules and doing } \\
\text { exercises }\end{array}$ & $100 \%$ & Very Active \\
\hline $\begin{array}{c}\text { Questions to the lecturer } \\
\begin{array}{c}\text { Provide answers to all questions } \\
\text { posed by lecturers and colleagues }\end{array}\end{array}$ & $57.75 \%$ & Active Enough \\
\hline $\begin{array}{c}\text { Collect assignments given by the } \\
\text { lecturer }\end{array}$ & $60 \%$ & Active \\
\hline Overall Average & $\mathbf{7 9 . 4 3 \%}$ & Very Active \\
\hline
\end{tabular}

The results of the analysis of student activities during the learning process with an average achievement level of $79.43 \%$ this number indicates that they are in the category of active students. To see a comparison of the things above can be seen in figure 5 below:

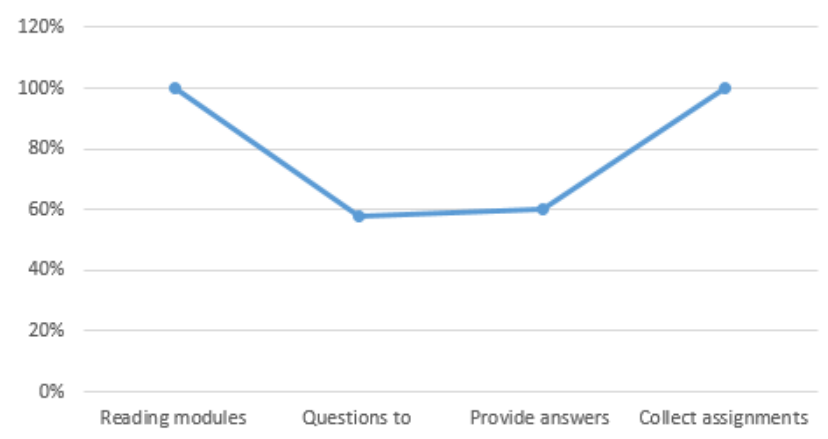

Fig. 5. Module Effectiveness Results. 


\section{Conclusion}

Based on the explanation of the results of the validator's assessment, student practicality, and student activity achievements, it can be described as follows: 1). Module Content, Construction, Language, and Display of the Module are at $91.12 \%$, this indicates that the module is in the very valid category. The description of the contents of the module is arranged systematically, this makes it easier for users to understand the module. The module is formulated in a learning unit that begins with the presentation of the material and evaluation. The presentation of the module is in accordance with the student's ability level. Ease for users (Learnability) of the module, namely the lecturer as a guide in the learning process with a value of $90 \%$ is in the practical category for users. Where the module has instructions, language according to student characteristics, can be used individually, and the exercises contained in the module can assist lecturers in providing direction to students to understand concepts. The purpose of designing the module is to make it easier for lecturers to guide and direct students in the learning process. The usability of the module for students (Efficiency) with a score of $93 \%$ is in the very practical category. Modules can help students in explaining concepts. It is also expected to be able to help lecturers direct students in the learning process. Effectiveness of Time is in the very practical category with an achievement value of $90 \%$. The modules developed are practically used by lecturers to guide students in the learning process. The results of the student learning evaluation can be declared as passing as many as 15 . The percentage of students who pass is $100 \%$. The purpose of the evaluation is to determine whether the students being taught already have the competencies that have been determined so that they are worthy of being given the next learning material. The practicality of the module proves that, 15 students who use the module in the learning process, $100 \%$ of students are declared complete. Furthermore, based on observations observed by one observer, generally students are active in the learning process. This shows that the module is very practical and effectively used in the learning process and can increase student interest in the teaching and learning process.

Modules have been produced in the form of online and print-based comics in the Research Methodology Course, which aims to increase students' knowledge, skills, interests, and learning outcomes during the teaching and learning process. The value of the validity of the module is at $91.12 \%$ in the very valid category. The practicality value of the module by students is at an achievement level of $90.3 \%$, it can be categorized as very practical and able to increase user interest in the learning process, and for student activities it is in the active category because it is in the percentage of $79.43 \%$. This shows that the module has had a positive influence on students' knowledge in studying and understanding the Elementary School of Arts and Skills Elementary School of Drawing Flora in the PGSD Departmen.

The suggestions in this study are to attract the interest and desire to learn a student not only pay attention to the aspect of teaching. But there are other aspects, namely related to interesting media or teaching materials, so that if two things between good teaching methods and interesting teaching media are combined into a unified whole, it will certainly produce better learning outcomes as well. Towards a generation that excels among students, especially PGSD students, it is necessary for the readiness of lecturers to innovate to find interesting new things to increase the attention and desire of students to study harder, whose main goal is to obtain good learning outcomes as well. It is also necessary to collaborate between fellow lecturers in producing further innovative studies, which seek other sides that have not been reached by previous researchers, to be investigated in a more interesting and useful finding. 
Acknowledgments. The author would like to thank the Dean of the Faculty of Education and the Head of the Department of PGSD who have given permission to the author to carry out this Faculty research, then to all students of the Department of PGSD, Faculty of Education, Unimed who have been involved in the implementation of this research, and in particular to the Institute for Research and Community Service, Unimed regarding the BOPTN-2021 funding for the implementation of this research, so that this research goes well.

\section{References}

[1] Sudewo S, et al. Perbandingan Buku Teks dengan Buku Bergambar. Perum Crisella III Desa Kolam: Personal Interview Results; 2021.

[2] Putri AF, Komariah K. Pengembangan Lembar Kerja Siswa (LKS) Bahan Ajar pada Mata Pelajaran Pengetahuan Bahan Makanan Bagi Siswa Kelas X Jasa Boga SMK Muhammadiyah 1 Moyudan. J Pend Tek Boga. 2016:01-07.

[3] Rusdi S, Riyana C. Media Pembelajaran Hakikat Pengembangan, Pemanfaatan, dan Penilaian. Bandung: Wacana Prima; 2007.

[4] Hernawan AH, Permasih H, Dewi L. Pengembangan Bahan Ajar. Direktorat UPI Bandung. 2012; 4(11):01-13.

[5] Slameto S. Belajar dan Faktor-Faktor yang Mempengaruhinya. Jakarta: Rineka Cipta; 2003.

[6] Aritonang KT. Minat dan Motivasi dalam Meningkatkan Hasil Belajar Siswa. J Pend Penabur. 2008; 7(10):11-12.

[7] Azis ACK. Pengembangan Materi Ajar Komik pada Mata Kuliah Menggambar Ilustrasi untuk Meningkatkan Motivasi dan Hasil Belajar Mahasiswa Seni Rupa dalam Membuat Penugasan KKNI Revitalisasi 2018. Medan: Research Results Report is not Published; 2018.

[8] Alwi H, et al. Kamus Besar Bahasa Indonesia. Jakarta: Balai Pustaka; 2002.

[9] Hamalik O. Manajemen Pelatihan Ketenagakerjaan Pendekatan Terpadu Pengembangan Sumber Daya Manusia. Jakarta: Bumi Aksara; 2007.

[10] Nurhasanah S, Sobandi A. Minat Belajar sebagai Determinan Hasil Belajar Siswa. J Pend Manaj Perkantoran (JPManper). 2016; 1(1):128-135.

[11] Rijal S, Bachtir S. Hubungan Antara Sikap, Kemandirian Belajar, dan Gaya Belajar dengan Hasil Belajar Kognitif Siswa. J Bioedukatikal. 2015; 3(2):15-20.

[12] Ching FDK. Menggambar: Sebuah Proses Kreatif. Jakarta: Erlangga; 2002.

[13] Thiangarajan S, et al. Instructional Development for Training Teachers of Exceptional Children. Washington DC: National Center for Improvement Education System; 1974.

[14] Arikunto. Prosedur Penelitian. Jakarta: Rineka Cipta; 1996. 